\title{
The Turonian-Coniacian stage boundary in Lower Saxony (Germany) and adjacent areas: the Salzgitter-Salder Quarry as a proposed international standard section
}

\author{
CHRISTOPHER J. WOOD, GUNDOLF ERNST AND GABRIELE RASEMANN
}

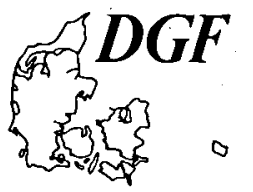

Wood, C. J., Ernst, G. \& Rasemann, G.: The Turonian-Coniacian stage boundary in Lower Saxony (Germany) and adjacent areas: the Salzgitter-Salder Quarry as a proposed international standard section. Bull. geol. Soc. Denmark, vol. 33 pp. 225-238, Copenhagen, September, 11th, 1984.

The litho- and biostratigraphy of the Turonian-Coniacian boundary succession of the Salzgitter-Salder limestone quarry (Lower Saxony) is described in the context of a proposed international standard section. Compared with other sections, Salder provides a thick continuous succession unaffected by condensation and/or non-sequences and with an abundance and diversity of macrofossils, notably inoceramids. The litho-, tephro-, and ecoevents which can be used to subdivide the sequence are described, from the base of the traditional 'Scaphiten-Schichten' up to the contact with the Emscher Marl. The events are ideal marker horizons for long-range correlation across NW Germany as far as England. The base of the Coniacian is taken at the entry-datum of Cremnoceramus? waltersdorfensis hannovrensis, coincident with the upper of two Didymotis events. This event is immediately followed by a major change in the inoceramid assemblages with the entry of Cremnoceramus? rotundatus. This latter change coincides with the traditional German Mittel-Oberturon boundary. The boundary problem is discussed in the context of ammonites, echinoids, foraminifera, and nannofossils. The inoceramid assemblages beneath the boundary have strong affinities with those of the uppermost Turonian Prionocyclus quadratus Zone in N. America: The boundary in Lower Saxony falls in the upper part of a distinctive lithostratigraphical unit of alternating marls and marly limestones (the so-called 'Grauweisse Wechselfolge'), intercalated between two predominantly limestone units. The geographical distribution and facies-differentiation of the 'Grauweisse Wechselfolge' in correlative sections of Lower Saxony is examined. The unit is the key to the recognition of the restricted boundary succession in sections where stratigraphical data are inadequate or lacking, e.g. the flooded quarries of Lüneburg and the Staffhorst mine-shaft. The probable equivalent of the 'Grauweisse Wechselfolge' in northern England is discussed, and additional comments are made on southern England, and northern Spain.

The Copenhagen Symposium (1983) proposals for recognising the base of the Coniacian are critically reviewed. The entry of $C$.? waltersdorfensis hannovrensis is demonstrated to be the only practicable criterion in many areas. The base of the Senonian, as defined in the Anglo-Paris Basin, is suggested to equate with the base of the 'Grauweisse Wechselfolge' and thus to be of late Turonian age.

Christopher J. Wood, Palaeontology Unit, British Geological Survey. Exhibition Road, London SW72DE, England. Gundolf Ernst and Gabriele Rasemann, Institut für Paläontologie der Freien Universität Berlin, Schwendenerstraße 8, D-1000 Berlin 33, Germany. April 27th, 1984.

In the context of the IGCP Project 58 ('MidCretaceous Events'), the 'Germany North' Working Group has investigated the litho- and biostratigraphy of the Turonian-Coniacian boundary successions in Lower Saxony.

Of these sections, the most important for the discussion of the boundary problem is the Salzgitter-Salder working limestone quarry of the Felswerke Peine-Salzgitter GmbH.

Other useful sections in the same area are the quarries and road-sections of Flöteberg, Kahnstein north of Langelsheim and Söhlde. There are also partial exposures of the boundary succession in the Sack Syncline. Additional, but now inaccessible sections are those of the Staffhorst mineshaft north-west of Hannover and the flooded quarries surrounding the Lüneburg saltdome (fig. 1).

In the Münster 'Basin' sections to the west (Teutoburger Wald and the area of Soest-Paderborn) only limited litho- and biostratigraphical information is available, and there are considerable problems in correlation both within the 'Basin' and with the successions in Lower Sax- 


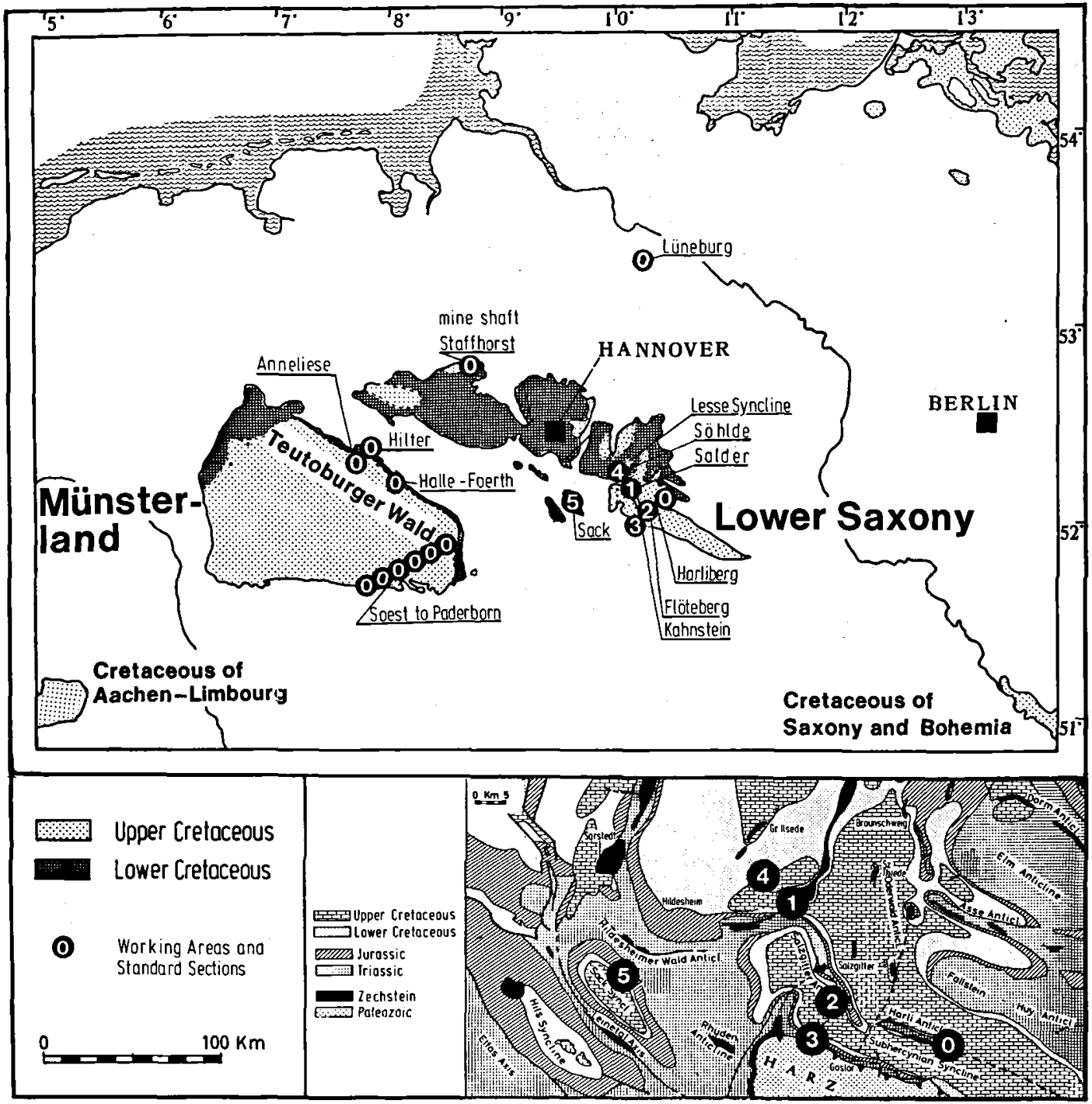

Fig. 1. Generalized map of northern German Cretaceous outcrops to show positions of the sections discussed.

ony. This area is consequently not considered in detail.

It is probable, however, that a direct correlation can be made both litho- and biostratigraphically between the Lower Saxony and English Northern Province successions, and, to a lesser extent, with successions in southern England and northern Spain.

This paper is primarily concerned with the Salzgitter-Salder quarry, which is described in detail below.

\section{The Salzgitter-Salder standard section}

Geographical and structural position: The quarry is situated on the southeast edge of the Lesse Syncline on the north side of the Lichtenberg structure near the village of Salzgitter-Salder. The Lesse Syncline lies within a structural zone where the basic Hercynian trend is overprinted by a SSW-NNE trending Rhine lineament. The syncline is a complex but basically asymmetrical structure, with shallow southeastern dips on the northern flank, and very steep northern dips 


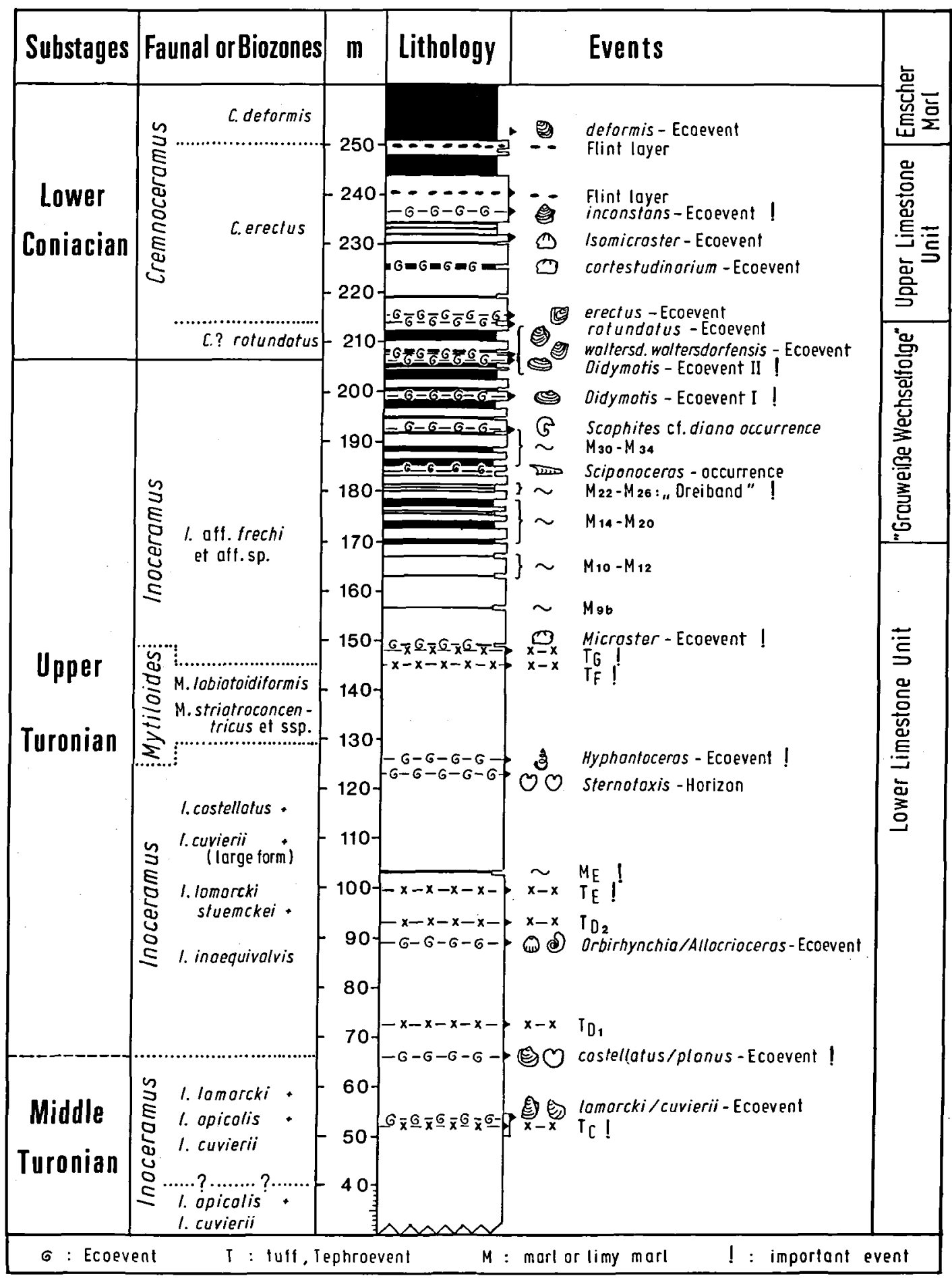

Fig. 2. Bio- and event stratigraphy of the Turonian and Lower Coniacian of the Salzgitter-Salder limestone quarry (Lower Saxony). 
(circa $70^{\circ}$ ) on the southern side adjacent to the Lichtenberg structure. The asymmetry of the syncline is the result of halokinetic movement of the Broistedt-Wendeburg salt-diapir and contemporaneous uplift of the Lichtenberg structure.

Lithofacies: There is a striking facies differentiation within a very short distance $(\mathrm{c} .6 \mathrm{~km})$ across the syncline from the northern margin with chalk sediments ('Söhlder Kreide') to the southern margin, where the sediments are predominantly marly limestones. The facies differentiation is linked to a marked difference in thickness, with thin sequences on the northern margin, and thick sequences on the southern margin within the foredeep of the Lichtenberg structure (fig. 4).

Faunal comparison: Concomitant with the facies change, there is a marked change in fauna, with sparse low-diversity faunas in the chalk succession and abundant high-diversity faunas in the marly limestone succession. This is seen particularly in originally aragonite-shelled fossils such as ammonites, which are exceedingly rare in the chalk facies.

Stratigraphy: The quarry is orientated parallel to the strike and exposes a $250 \mathrm{~m}$ succession, ranging from the apicalis/cuvierii Zone of the Middle Turonian up to the contact with the Lower Coniacian Emscher Marl. Within the succession there is a significant change from relatively calcareous massive limestones below to a rhythmic sequence of marls and marly limestones, which Ernst \& Schmid (1979a, p. 20) called the 'Grauweisse Wechselfolge' (fig. 2).

The succession can be subdivided by means of numerous litho-, tephro-, and ecoevents (fig. 2). The tephro- and some of the ecoevents, in particular, permit excellent correlation with successions throughout northwestern Germany (Ernst, Schmid \& Seibertz 1983, figs. 2-5). By means of the event framework and the detailed measured section, it is possible to make accurately horizoned bed by bed collections of macrofossils. In the Turonian-Coniacian boundary sequence large bedding planes are exposed from which fossil 'populations' can be collected.

In this latter part of the succession, and up to the contact with the Emscher Marl, the macrofaunas are extremely abundant and relatively di- verse, notably the inoceramids and, to a lesser extent, the echinoids and brachiopods. Ammonites, predominately heteromorphs, occur sparsely throughout the boundary succession. In addition, the boundary succession is also characterized by two levels with the bivalve Didymotis.

\section{Salzgitter-Salder as a reference section:}

The advantages are:

1) a thick sequence without obvious evidence of breaks or non-sequences; 2) excellent correlation-potential, on the basis of numerous litho-, tephro- and ecoevents; 3) abundant macrofaunas, allowing the integration of inoceramid biostratigraphy with data on ammonites, echinoids and Didymotis; 4) presence of microfauna, predominantly planktonic foraminifera, calcispheres and nannofossils; 5) continuous exposure; quarrying activity will provide fresh exposures for the foreseeable future; 6) detailed measured section with accurate bed-by-bed descriptions (Rasemann 1984, unpubl. thesis).

The disadvantages are:

1) extensive dissolution and deformation of fossils as a result of tectonic compaction and shearing (Langheinrich \& Plessmann 1968);

2) difficulty of extracting the microfossils and developing the macrofossils from their matrix; 3) the absence of critical ammonites.

The advantages of the Salzgitter-Salder quarry for the investigation of the Turonian-Coniacian boundary problem far outweigh the disadvantages. There is no evidence of the condensation and/or non-sequence that is found at the top of the Turonian in most other areas of western Europe. Of particular importance is the succession of inoceramid assemblages, which is probably one of the most complete currently available in Europe.

In view of all these advantages, we formally propose that this outstanding section should be regarded as an international standard section.

\section{Event stratigraphy of the Turonian- Coniacian boundary succession in Salder}

In the present context we may disregard the lower part of the Salder succession and begin 
with the description of the major events of the Upper Turonian.

Below the boundary succession there is a distinctive sequence of five important events (fig. 2). These comprise in ascending order the marl layer $\mathrm{M}_{\mathrm{E}}$, the Hyphantoceras ecoevent, the closely spaced tephroevents $F$ and $G$, and the overlying Micraster Marl or ecoevent.

Marl $M_{E}$ : The $M_{E}$ comprises a c. $35 \mathrm{~cm}$ thick marl. About $3 \mathrm{~m}$ below there is a thin tephroevent $\left(T_{E}\right)$. The $M_{E}$ is a major lithological marker horizon which can be traced right across northwestern Germany to England, where it corresponds to the North Ormsby Marl/Grimes Graves Marl/Bridgewick Marl 1 in northern, eastern and southern England respectively (see Mortimore \& Wood, in press). In England, these marls everywhere lie within a sequence of large flints (the high Turonian flint maximum of Mortimore \& Wood, in press), and it is significant that flint is locally developed in this level in the otherwise virtually flintless successions of Flöteberg, Kahnstein, and Söhlde.

Hyphantoceras event: This event is a well known and geographically widespread major eustato(regressive) event, characterised by a preferential preservation of originally aragonite-shelled fossils, particularly ammonites. Of the rich and diverse ammonite assemblage, two of the commonest species are the eponymous Hyphantoceras reussianum (d'Orbigny) and Scaphites geinitzii d'Orbigny and related forms, from which the 'Scaphiten-Schichten' of the traditional German nomenclature derive their name. The assemblage belongs to the late Turonian Subprionocyclus neptuni Zone of the international ammonite scheme. This event is an expression of a major interregional event, represented elsewhere in Europe by the terminal hardground of the Chalk Rock of southern England (Bromley \& Gale 1982; Mortimore \& Wood, in press).

The inoceramids of the Hyphantoceras event are predominantly $I$. ex gr. costellatus sensu Tröger; the Micraster belong to the corbovis group (Ernst, Schmid \& Seibertz 1983, p. 538).

Tephroevents $T_{F}$ and $T_{G}$ and overlying Micraster Marl $\mathrm{M}_{\mathrm{G}}$

These three closely-spaced events in combination comprise a highly distinctive marker sequence between the Hyphantoceras event and the stage boundary succession. The use of these events, in particular of the tephroevents, for correlation in Lower Saxony was demonstrated by Ernst, Schmid \& Seibertz (1983, p. 547-548).

The two tephroevents overlie beds characterised by an acme-occurrence of large Mytiloides ex gr. striatoconcentricus (Gümbel) with subordinate Inoceramus longealatus Tröger. This $M y$ tiloides occurrence succeeds a thin Mytiloides fiegei (Tröger) event. Between and above the two tephroevents there is a significant change in the inoceramids, with replacement of the $M y$ tiloides-dominated assemblages by assemblages of thin-shelled inoceramids of the ' $I$. aff. frechi' Zone.

The overlying Micraster event is characterised by the entry of 'advanced' Micraster of the bucailli lineage, which are most abundant within the Micraster Marl itself.

The above-mentioned sequence of Mytiloides assemblages appears to be recognisable in the nodular chalk facies of the higher Sternotaxis planus Zone of southern England, where it is followed by a significant change within the main Micraster lineage.

\section{Lower Didymotis ecoevent (DI)}

Above the Micraster Marl, there is a c. $50 \mathrm{~m}$ succession within which the change from massive limestones to the sequence of alternating marls and marly limestones takes place. This succession is relatively poorly fossiliferous, and no significant ecoevents have so far been recognised.

Above this sequence follows a $7 \mathrm{~m}$ succession within which there is a major progressive faunal turnover. At the base of this succession (bed MK $39 \mathrm{~b}$ ) there is a sudden increase in faunal diversity, marked by the entry in flood abundance of Didymotis sp., constituting the lower Didymotis event.

Associated with the Didymotis is a sparse inoceramid assemblage dominated by a thinshelled labiatoid form with a conspicuous flared posterior wing: this is the index fossil of the 'Inoceramus aff. frechi' Zone of Ernst, Schmid \& Seibertz (1983). Other members of the assemblage include Mytiloides? cf. frechi (Flegel) and $M$.cf. lusatiae (Andert).

'I. aff. frechi' appears to fall between $M$. frechi 
and $M$. lusatiae as interpreted by Kauffman (1977, pl. 10, figs. 17, 21) in North American material. Comparable European forms were figured by Simionescu (1899, pl. 2, fig. 3) from the Turonian-Coniacian of Rumania as Inoceramus labiatus Schlotheim var. regularis, and later by Pauliuc (1968, pl. 5) as I. sublabiatus Müller. The relationship between ' $I$. aff. frechi' and $I$. vancouverensis longealatus Tröger (Tröger 1967, pl. 10, fig. 2), which likewise has an extremely extended posterior wing, is unclear.

The ' $I$. aff. frechi' assemblage of Salder compares closely with the inoceramid assemblage that characterises the uppermost Turonian Prionocyclus quadratus ammonite zone in the USA (Cobban: pers. comm.). In this context, the recent find of an unequivocal Prionocyclus sp. from $3 \mathrm{~m}$ above the Micraster Marl and below the equivalent of the 'Grauweisse Wechselfolge' in the Annelise quarry, Bad Laer, Teutoburger Wald (Kaplan: pers. comm. and in prep.) is of outstanding importance, and supports the high Turonian position of the German ' $I$. aff. frechi' Zone. This locality has also yielded to Kaplan a single example of Prionocycloceras cf. germari (Reuss) from a level in the equivalent of the 'Grauweisse Wechselfolge' below the restricted boundary succession.

The record of Didymotis in Salder with an apparently latest Turonian inoceramid assemblage is noteworthy, because Didymotis is elsewhere generally restricted to the Coniacian (see discussion in Herm, Kauffman \& Wiedmann 1979, p. 49).

\section{Upper Didymotis ecoevent (D II)}

Approximately $7 \mathrm{~m}$ above the lower Didymotis event, a second Didymotis flood occurrence is found in bed MK 45. Between Didymotis I and II significant inoceramid assemblages occur in beds MK 41 and 43. In bed 41 there is a minor acme of 'I. aff. frechi'. In bed 43 the inoceramid assemblage comprises predominantly $M$. labiatoidiformis (Tröger) and the larger $M$. labiatoidiformis (sensu Keller 1982); the same bed has provided the only record of Didymotis between the two Didymotis events. The overlying bed 44 just beneath the upper Didymotis event is a marl barren of inoceramids.

The Didymotis of the upper event are more abundant, better preserved, somewhat larger, and more elongate than those in the lower occurrence. They appear to be close to $D$. costatus (Frič, 1893) described from the Lower Coniacian of Bohemia (Závorka 1979, pl. 1-2). This species may be conspecific with $D$. uermoesensis (Simionescu) from a presumed equivalent level in Rumania (Simionescu 1899; Pauliuc 1968, pl. 25, fig. 3). The relationship between these European forms and the Lower Coniacian $D$. trinidadensis Sommermeier and $D$. variabilis Gerhardt from Trinidad and adjacent areas (see Imlay 1955; Kauffman 1978) has not been investigated.

Associated with the Didymotis in D II is an inoceramid assemblage comprising almost exclusively small rounded forms of Cremnoceramus? waltersdorfensis hannovrensis (Heinz) with subordinate C.? w. waltersdorfensis (Andert). In addition, a single specimen of $C$. aff. rotundatus (Tröger non Fiege) was found.

The inoceramids in the upper Didymotis ecoevent constitute the lowest unequivocal Lower Coniacian inoceramid assemblage in the Salder succession, and we therefore recommend that the base of the Coniacian should be drawn at this level.

waltersdorfensis waltersdorfensis ecoevent This event immediately overlies D II and comprises a flood occurrence of small $C . ?$ waltersdorfensis waltersdorfensis, associated with rare large Didymotis in a marl (bed KM 46).

\section{rotundatus ecoevent}

The inoceramid assemblage of this event (bed K 47) comprises predominantly $C$.? rotundatus (Tröger non Fiege) together with transitions to $C$. erectus (Meek) and members of the waltersdorfensis complex. Didymotis has not been found in or above this level.

Above the rotundatus event follows a highly fossiliferous sequence in which several further ecoevents can be distinguished, e.g. the waltersdorfensis hannovrensis event (bed MK 52d) with large sized individuals of this subspecies, and the erectus event (bed MK 53a).

cortestudinarium ecoevent

This relatively broad event is characterised by scattered occurrences of Micraster of the cortestudinarium group.

The only extant specimen of the original syn- 


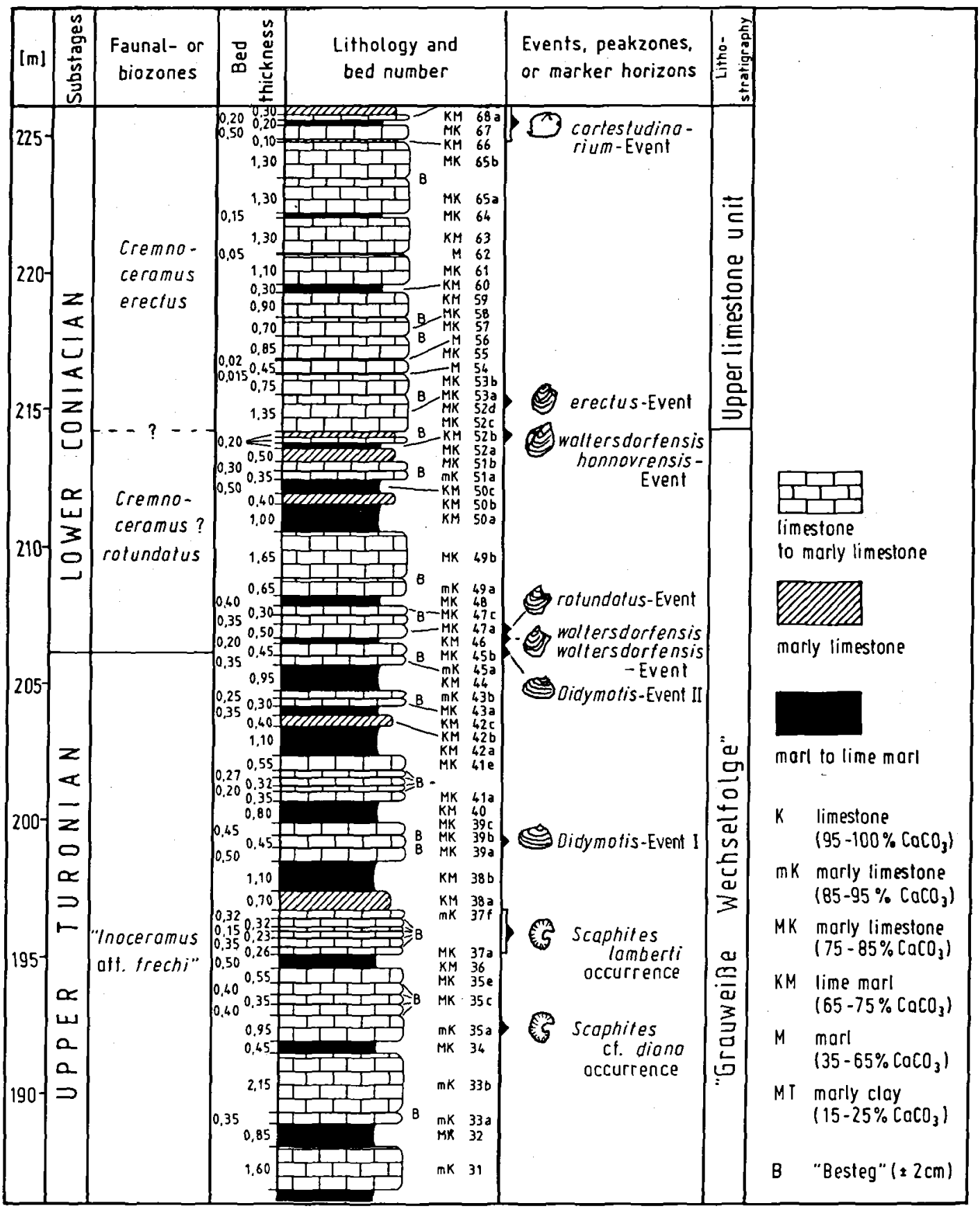

Fig. 3. Detailed litho- and event stratigraphy of the Turonian-Coniacian boundary succession in the Salzgitter-Salder limestone quarry (Lower Saxony). 


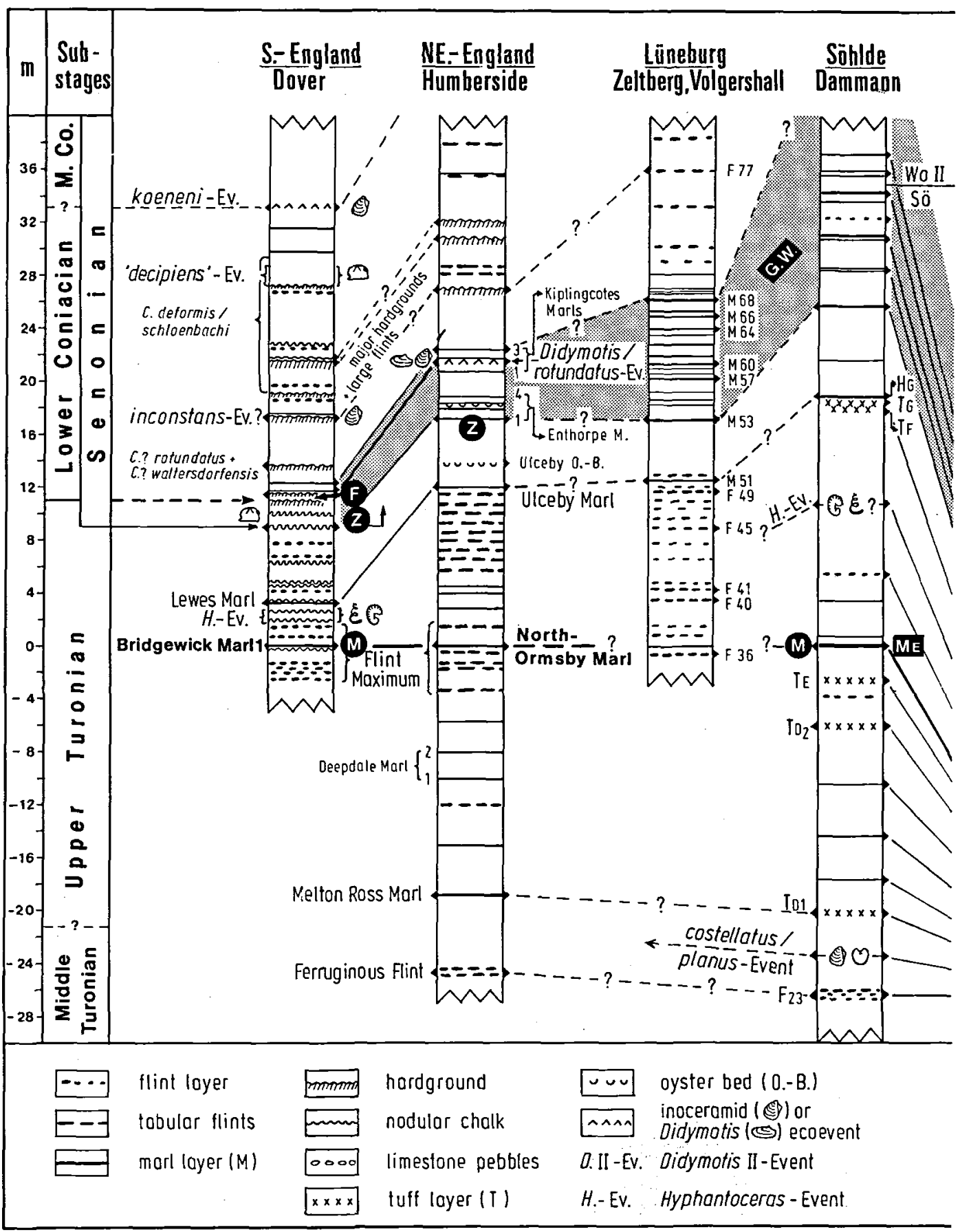

Fig. 4. Schematic correlation diagram of the Turonian-Coniacian boundary successions of Lower Saxony and England. 


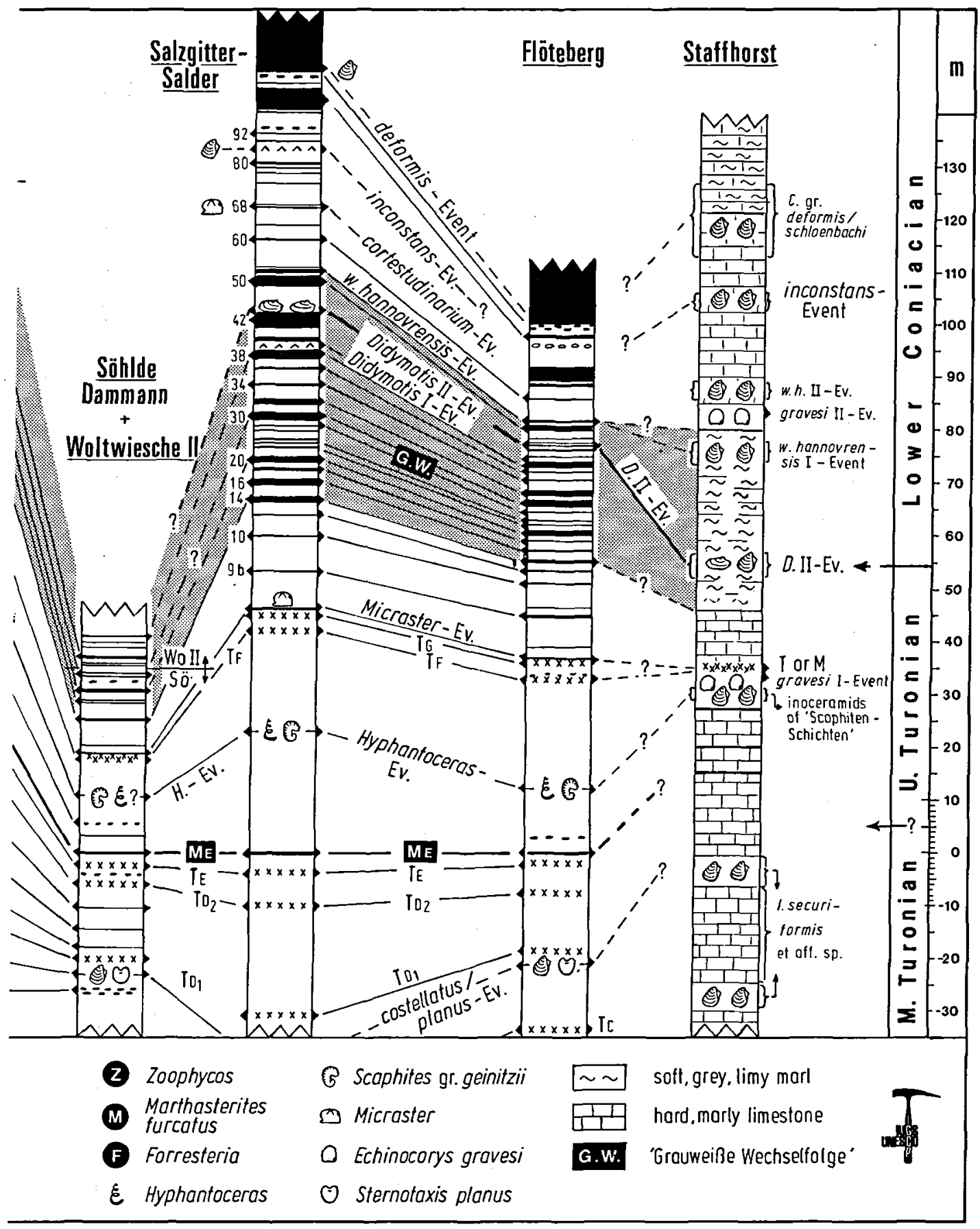


type material of $M$. cortestudinarium (Goldfuss, 1826) is probably conspecific with $M$. decipiens (Bayle, 1878), contrary to the opinions expressed by Stokes (1975), Fouray (1981) and Drummond (in press). The specimen is free from matrix, but the sediment preserved inside the test is a recrystallised chalk, indicating a provenance either from the Anglo-Paris Basin or from the chalk of Lüneburg (N. Germany). Provenance from the localities cited by Goldfuss (Quedlinburg, Coesfeld, Maastricht) can be completely excluded.

The entry of $M$. decipiens was proposed by the French Senonian Working Group (Pomerol 1983) as a criterion for recognizing the base of the Senonian/Coniacian.

\section{Isomicraster ecoevent}

In Bed MK 75 there is a flood occurrence of an undescribed species of Micraster (Isomicraster) sp. (Ernst 1970: fig. 4), associated with a diverse inoceramid assemblage, dominated by $C$. erectus, and transitions between $C . ?$ waltersdorfensis and C. inconstans (Woods). In addition there are sparse Scaphites lamberti (de Grossouvre).

\section{inconstans ecoevent}

Within bed $85 \mathrm{a}, C$. inconstans occurs in flood abundance.

\section{deformis ecoevent}

At the base of the Emscher Marl (bed KM 114), definite large $C$. deformis (Meek) first appear in the succession. The entry of this species was proposed by Seibertz (1983) as a criterion for recognizing the base of the Coniacian.

\section{General comments on the boundary succession in Lower Saxony}

As shown above, the Turonian-Coniacian boundary in Salder falls within the higher part of the lithostratigraphic unit of alternating marls and marly limestones (so-called 'Grauweisse Wechselfolge'). The 'Grauweisse Wechselfolge' can thus provide a potential key to the location of the stage boundary in stratigraphically poorly known exposures, mine-shafts and boreholes. It is probable that the unit can be identified in geophysical logs, but this point has not been investigated.
The 'Grauweisse Wechselfolge' is identifiable in all the sections studied. Five of these sections Salder, Flöteberg, Staffhorst, Söhlde and Lüneburg - are shown in the correlation diagram (fig. 4).

The four southernmost localities - Salder, Flöteberg, Kahnstein and Sack - lie palaeogeographically in a relatively marginal position, and the lithostratigraphy and thickness of the succession is similar in all cases. The 'Grauweisse Wechselfolge' in these sections is developed as a sequence of alternating marly limestones and thick marls intercalated between two predominantly limestone units.

In the case of a more distal position, such as Lüneburg, the succession is developed in chalk facies, and the marls within the 'Grauweisse Wechselfolge' are extremely thin relative to the chalk units. Some of the 'marl seams' of Lüneburg have been considered to be volcanogenic (Valeton 1960). If this really is the case, the origin of some of the thick marls of the southern area would have to be reconsidered, particularly those that are devoid of fossils.

The equivalent of the 'Grauweisse Wechselfolge' of Lüneburg is flintless and is intercalated between two flinty, more massive limestone units, which correspond to the poorly flinty limestone units in the southern area. This general picture of units is also recognisable in the chalk of the English Northern Province, which emphasizes the interregional character of the sequence of depositional phases. The Söhlde succession is intermediate in thickness and lithofacies between that of Lüneburg and the group of sections of Salder type. Also intermediate in character is the Staffhorst succession, which is closer to chalk facies than the Salder type, but is comparable with Salder in the richness and diversity of macrofaunas (Fig. 4).

The Turonian-Coniacian boundary, as used here, falls everywhere in the higher part of the 'Grauweisse Wechselfolge' with the exception of Staffhorst, where it appears to lie significantly lower in this unit. This discrepancy is apparently due to an exceptional expansion of the higher part of the 'Grauweisse Wechselfolge' compared to Salder. The expansion may be a compensation effect for the relative condensation of the underlying Turonian (see Fig. 4). 


\section{Comments on the boundary succession in England and Spain}

The 'Grauweisse Wechselfolge' can be identified readily in the Chalk of the English Northern Province. In this area, the equivalent succession includes $6-7$ thin marls of 'buttery' montmorillonitic character, similar to those of Lüneburg. These are the Enthorpe and Kiplingcotes Marls of Wood \& Smith (1978). This sequence of marl seams is intercalated between two flint-rich chalk units. The lower unit is extremely rich in closelyspaced tabular flints, and includes the equivalent of the marl event $\mathrm{M}_{\mathrm{E}}$ near the base (Mortimore \& Wood, in press). The sequence underlying the 'Grauweisse Wechselfolge' in Lüneburg is likewise rich in tabular flints.

In the upper part of the unit with marl seams, there is a dramatic increase in faunal diversity below Kiplingcotes Marl 2 with the entry of Lower Coniacian inoceramids and Didymotis in flood abundance. Just below this level the ichnofossil Zoophycos is conspicuous.

In southern England, the higher part of the Sternotaxis planus Zone is marked by the sudden entrance of Zoophycos, approximately coincident with a major change in the echinoid assemblages. This is the level taken by French workers in the Anglo-Paris Basin as the base of the Senonian (Bailey et al. 1984).

The Zoophycos beds terminate in a major hardground, which has yielded a single specimen of the basal Coniacian ammonite index Forresteria petrocoriense (Coquand) (Bailey et al. 1983, 1984). The succession above the hardground contains basal Lower Coniacian inoceramids, such as C.? rotundatus and $C$.? waltersdorfensis. It is probable, therefore, that the lower part of the 'Grauweisse Wechselfolge' is represented by the chalks with Zoophycos, and that the higher part is condensed within the hardground.

\section{Northern Spain}

There is some similarity between the TuronianConiacian boundary succession in southern England and that found in the so-called 'Barranca' between Pamplona and Alsasua (Navarra) in northern Spain. In this restricted area, the boundary succession is extremely condensed into a sequence of closely-spaced hardgrounds. Im- mediately overlying the main hardgrounds are found nodular calcareous marls rich in large Zoophycos. These marls contain basal Coniacian ammonites, such as Forresteria and Peroniceras together with Cremnoceramus? waltersdorfensis hannovrensis and a diverse echinoid assemblage. The echinoids comprise predominantly Conulus and Echinocorys gravesi together with Micraster ex gr. cortestudinarium. This locality is of outstanding importance because it demonstrates the first definite co-occurrence in Europe of basal Coniacian inoceramids and ammonites (Berlin University Working. Group) Ernst, Küchler et al., in prep.).

\section{Turonian-Coniacian boundary proposals}

At the 'Symposium on Cretaceous Stage Boundaries' in Copenhagen 1983 the following proposals for recognising the base of the Coniacian were made:
a) entry of Marthasterites furcatus (Deflandre)
b) entry of Micraster decipiens (Bayle)
c) entry of Forresteria (Harleites) petrocoriense (Coquand)
d) entry of Cremnoceramus? waltersdorfensis hannovrensis (Heinz)
e) entry of Cremnoceramus deformis (Meek) Marthasterites furcatus: Although the entry level of this distinctive species in widely taken by nannofossil workers to mark the base of the Coniacian, this criterion is demonstrably inapplicable in NW-Europe. In the chalk facies of the Söhlde quarry, $M$. furcatus has been found in $\operatorname{marl} \mathrm{M}_{\mathrm{E}}$, the major Upper Turonian marker horizon (F. Naji, pers. comm.). This level lies significantly below the Hyphantoceras event, i.e. below the acme-occurrence of the ammonites of the Late Turonian Subprionocyclus neptuni Zone. A comparable entry level of $M$. furcatus in southern England is reported by Bailey et al. (1984, this vol.). A second minor occurrence of this fossil, however, is found near the base of the Coniacian in the latter area (Crux 1980).

Micraster decipiens: The fact that $M$. decipiens is apparently conspecific with $M$. cortestudinarium has already been discussed, the name $M$. cortestudinarium having clear priority. The inter- 
pretation of $M$. cortestudinarium/decipiens is highly subjective and the names have been applied inconsistently by different workers in the same area. Pomerol (1983) and his co-workers take the entry of their $M$. decipiens in the AngloParis Basin to mark the base of the Senonian and therefore of the Coniacian. In southern England, this level appears to coincide with the base of the equivalent of the 'Grauweisse Wechselfolge', and thus falls into the Upper Turonian.

It must be emphasized that the conventional picture of Micraster evolution is open to question, and that many of the established 'species' may be nothing more than short-lived and local ecomorphs of a single long-ranging species. Such ecomorphs are unsuited for the identification of stage boundaries.

Forresteria (Harleites) petrocoriense: Although Forresteria is widely distributed, it has the considerable disadvantage that it is extremely rare or even absent in basinal chalks and comparable sediments. The isolated examples discussed in this paper from southern England and northern Spain are linked with condensed sequences and shallow-water environments, as are the records from the higher part of the Lower Coniacian (Cremnoceramus schloenbachi Zone) in the Soest - Paderborn area of the Munster 'Basin'.

The apparent absence of Forresteria in Lower Saxony is not simply a question of preservation, as heteromorph ammonites such as Scaphites and Sciponoceras are comparatively well represented in our comprehensive collections from the boundary succession. Forresteria is, however, recorded from the equivalent of the limestone unit above the 'Grauweisse Wechselfolge' in the Schlangen quarry, Teutoburger Wald (Kaplan: pers. comm. and in prep.), so that it is possible that it may yet be found at this level in Lower Saxony.

Cremnoceramus? waltersdorfensis hannovrensis. The relevance of this inoceramid to the recognition of the base of the Coniacian has been reviewed in Herm, Wiedmann \& Kauffman (1979, p. 78). The advantages of this taxon are wide geographical distribution, abundance and relative facies-independence. In all these respects, it is a better index fossil than Forresteria. Rare isolated records of $C$ ? $w$. hannovrensis below our restricted boundary succession in the Sack (Keller 1982, figs 17-18) and Kahnstein (Liever 1980) are at variance with the results from Salder and require further investigation. An important fact is that the entry of $C$ ? $w$. hannovrensis in Salder and nearby exposures is demonstrably coincident with the upper Didymotis event. Contrary to the situation in other areas, the base of the Coniacian as used here, coincides with the approximate top of the range of Didymotis, rather than with the base.

Cremnoceramus deformis. The entry of this species is significantly higher than the base of the Coniacian as taken here (Bailey et al. 1984). There is, in any case controversy regarding speciation within this group of Cremnoceramus, and the concept of $C$. deformis has been loosely interpreted outside North America. In fact, Seibertz (Copenhagen Symposium lecture 1983) has made the interesting suggestion that the supposedly successive 'species' - rotundatus, erectus, deformis, schloenbachi - were contemporaneous ecomorphs occupying different positions on the continental slope, and that they therefore should not be used in defining zones or in recognising the base of the Coniacian Stage.

\section{Discussion and concluding remarks}

Out of the five proposals, those relating to $M$. furcatus, $M$. decipiens, and $C$. deformis respectively are totally inapplicable. We have also shown that there are serious disadvantages in the use of Forresteria in many European areas. The remaining proposal, however, - the entry of $C$.? waltersdorfensis hannovrensis - is ideally suited in view of the wide distribution, facies-independance, and abundance of this subspecies. This proposal has the additional advantage that the entry level of this inoceramid is approximately coincident with that of Forresteria.

In lower Saxony, apart from rare questionable lower records, C.? $w$. hannovrensis enters suddenly and in flood abundance. Less than a metre above, there is an equally conspicuous entry of C.? rotundatus - the rotundatus event of this paper -, which was taken by Bräutigam (1962) to define the boundary between the Mittel- and. Oberturon. The base of the Coniacian taken by 
us coincides with our upper Didymotis event D II.

In terms of ammonite stratigraphy, only Scaphites provides useful data in Lower Saxony (Kaplan pers. comm.). The long ranging Upper Turonian species $S$. geinitzii cuts out in Salder within the Upper Turonian ' $I$. aff. frechi' Zone in bed 35, i.e. within the 'Grauweisse Wechselfolge' and some $12 \mathrm{~m}$ below the stage boundary adopted here. The remainder of the 'Grauweisse Wechselfolge', including the restricted boundary succession, and the lower part of the overlying limestone unit up to bed 66 (the cortestudinarium event) is characterized by $S$. lamberti doylei Wright, a subspecies that enters just above the Hyphantoceras event. S. l. lamberti de Grossouvre, a typical Coniacian form, enters at the level of the cortestudinarium event together with $S$. kieslingwaldensis Langenhan \& Grundey. There is thus no significant change in the scaphitids across the stage boundary.

Although diagnostic ammonites such as Forresteria and Barroisiceras have not been found in Salder, the choice of the upper Didymotis event as the base of the Coniacian is strongly supported by the inoceramids of the underlying ' $I$. aff. frechi' Zone. This latter assemblage has strong affinities with the assemblage of the uppermost Turonian Prionocyclus quadratus ammonite Zone of North America. There is also a striking similarity between the lowest Coniacian inoceramid assemblages of Salder and those of $\mathrm{N}$. America, in which small C.? waltersdorfensis hannovrensis and $C$.? rotundatus likewise co-occur.

In terms of foraminiferal stratigraphy, Bräutigam (1962) reported a significant change in the planktonic foraminiferal assemblages in all key localities of eastern Lower Saxony, i.e. Salder, Flöteberg and Kahnstein. This change is coincident with his Mittel-Oberturon boundary and is marked by a sudden increase of Globotruncana paraventricosa (Hofker). This change was also reported by Koch (1977, table 1) from chalky facies in the area of the 'Pompeckjsche Scholle'. Here the beginning of the acme-occurrence of $G$. paraventricosa is stated to be coincident with the entry-datum of Stensioeina granulata levis Koch (Koch 1977, p. 16, 34-35). Rare specimens of this subspecies also occur at an equivalent level in șouthern England (Bailey et al. 1984).
This dramatic turnover in macro- and microfaunas in Salder with the entry of a completely new inoceramid assemblage coincident with a marked change in the foraminiferal fauna provides additional support for the selection of the upper Didymotis event as the base of the Coniacian. Such a major faunal turnover in several fossil groups is an ideal criterion for the identification of a stage boundary.

Acknowledgements. This paper represents a contribution to the IGCP Major Project 58 'Mid-Cretaceous Events' of the IUGS. The work was supported by the Deutsche Forschungsgemeinschaft. C. J. Wood publishes by permission of the Director BGS (NERC).

\section{Dansk sammendrag}

Turonien-coniacien grænsen i Nedre Sachsen er beskrevet og et profil i Salzgitter-Salder kalkstensbrud foreslået som internationalt standardprofil.

Der gøres rede for "events" af lithologisk, vulkansk, økologisk og biostratigrafisk art og det påvises, at en rakke af disse "events" kan benyttes til korrelation over store dele af NV Europa. Basis of coniacien defineres ved første tilsynekomst af Cremnoceramus? waltersdorfensis hannovrensis. Basis af senonien, som defineret i Pariserbassinet, bliver herved af sen turonien alder.

\section{References}

Bailey, H. W., Gale, A. S., Mortimore, R. N., Swiecicki, A. \& Wood, C. J. 1983: The Coniacian - Maastrichtian Stages of the United Kingdom, with particular reference to southern England. Newsl. Stratigr. 12, 1, 29-42.

Bailey, H. W., Gale, A. S., Mortimore, R. N., Swiecicki, A. \& Wood, C. J. 1984: Biostratigraphical criteria for the recognition of the Coniacian to Maastrichtian Stage boundaries in the chalk of north-west Europe, with particular reference to southern England. Bull. geol. Soc. Denmark.

Brăutigam, F. 1962: Zur Stratigraphie und Paläontologie des Cenomans und Turons im nordwestlichen Harzvorland. Dissertation Techn. Hochschule Braunschweig, 261 pp.

Bromley, R. G. \& Gale, A. S. 1982: The Lithostratigraphy of the English Chalk Rock. Cretaceous Research 3, 273-306.

Crux, J. A. 1980: A biostratigraphical study of Upper Cretaceous calcareous nannofossils from south-east England and north France. Unpubl. Ph.D. thesis, University of London, 299 pp.

Drummond, P. V. O. (in press): The Micraster biostratigraphy of the Senonian White Chalk of Sussex, Southern England. Géologie Méditerranéenne.

Ernst, G. 1970: Faziesgebundenheit und Ökomorphologie bei irregulären Echiniden der nordwestdeutschen Oberkreide. Paläont. Z. 44, 41-62.

Ernst, G. \& Schmid, F. 1979: Multistratigraphische Untersuchungen in der Oberkreide des Raumes BraunschweigHannover. Aspekte der Kreide Europas. IUGS Ser. A, 6, 11-46. 
Ernst, G., Schmid, F. \& Seibertz, E. 1983: Event-Stratigraphie im Cenoman und Turon von NW-Deutschland. Zitteliana 10, 531-554.

Fouray, M. 1981: L'Évolution des Micraster (Échinides, Spatangoïdes) dans le Turonien-Coniacien de Picardie Occidentale (Somme). Intérêt biostratigraphique. Annales de Paléontologie (Invertébrés) 67, 2, 81-127.

Herm, D., Kauffman, E. \& Wiedmann, J. 1979: The age and depositional environment of the 'Gosau'-Group (Coniacian-Santonian), Brandenberg/Tirol, Austria. Mitt. Bayer. Stattsslg. Paläont. hist. Geol. 19, 27-92.

Imlay, R. W. 1955: Stratigraphic and geographic range of the Late Cretaceous pelecypod Didymotis. Jour. Paleont. 29, $3,548-550$.

Kauffman, E. G. 1977: Illustrated guide to biostratigraphically important Cretaceous macrofossils, Western Interior Basin, USA. The Mountain Geologist 14, 225-274.

Kauffman, E. G. 1978: Middle Cretaceous bivalve zones and stage implications in the Antillean Subprovince, Caribbean Province. Ann. Mus. d'Hist. nat. Nice 4, 1976: xxx. 1-11.

Keller, S. 1982: Die Oberkreide der Sack-Mulde bei Alfeld (Cenoman-Unter-Coniac): Lithologie, Biostratigraphie und Inoceramen. Geol. Jb. A 64, 3-171.

Koch, W. 1977: Stratigraphie der Oberkreide in Nordwestdeutschland (Pompeckjsche Scholle). Teil 2: Biostratigraphie in der Oberkreide und Taxonomie von Foraminiferen. Geol. Jb., A 38, 11-123.

Langheinrich, G. \& Plessmann, W. 1968: Zur Entstehungsweise von Schieferungs-Flächen in Kalksteinen (Turon-Kalke eines Salzauftriebs-Sattels im Harz-Vorland). Geol. Mitt. 8, 111-142.

Liever, H. 1980: Profilaufnahme und Kartierung der Oberkreide im Kahnsteingebiet (Nördliches Harzvorland). Unpubl. Diplom thesis. Clausthal. Zellerfeld, 133 pp.

Mortimore, R. N. \& Wood, C. J. 1984: The distribution of flint in the English Chalk, with particular reference to the 'Brandon Flint Series' and the high Turonian flint maximum. In Sieveking, G. de G. \& Hart, M. B. (eds): The scientific study of flint and chert: papers from the Fourth International Flint Symposium. Cambridge (in press).
Pauliuc, S. 1968: Studiul geologic al Perśanilor centrali cu privire specială la Cretacicul Superior. Studii tehnice si economice, ser. J, 4, 134 pp.

Pomerol, B. 1983: The correlation of the Turonian/Senonian Boundary in the Senonian stratotype area and in southern England. Abstracts Symp. Cretaceous Stage Boundaries, Copenhagen 1983, 161-165.

Rasemann, G. 1984: Stratigraphie der Salzgitterer Struktur zwischen Osterlinde und Salder unter besonderer Berücksichtigung der Oberkreide (Turon-Coniac). Unpubl. Diplom thesis. Freie Universität Berlin. 197 pp.

Seibertz, E. 1983: The NW-European Inoceramus biozonation in NE-Mexican standard sections: $A$ key to define worldwide the Turonian/Coniacian Stage Boundary (Mid-Cretaceous). Abstracts Symp. Cretaceous Stage Boundaries, Copenhagen 1983, 186-190.

Simionescu, J. 1899: Fauna cretacică superióră de la Ürmös (Transilvania). Acad. Română 1 (4), 239-275.

Stokes, $R$. B. 1975: Royaumes et provinces fauniques de Crétacé établis sur la base d'une étude systématique du genre Micraster. Mém. Mus. nat. Hist. nat. C 31, 94 pp.

Tröger, K.-A. 1967: Zur Paläontologie, Biostratigraphie und faziellen Ausbildung der unteren Oberkreide (Cenoman bis Turon). Teil I: Paläontologie und Biostratigraphie der Inoceramen des Cenomans und Turons Mitteleuropas. Abh. staat. Mus. Miner. Geol. 12, 13-207.

Valeton, I. 1960: Vulkanische Tuffiteinlagerungen in der nordwestdeutschen Oberkreide. Mitt. geol. Staatsinst. Hamburg $29,26-41$.

Wood, C. J. \& Smith, E. G. 1978: Lithostratigraphical classification of the Chalk in North Yorkshire, Humberside and Lincolshire. Proc. Yorks. Geol. Soc. 42, 263-287.

Zázvorka, v. 1979: Sphenoceramus costatus (Fric, 1893) emend. Zázvorka, 1979 (Inoceramidae) z Coniaku svrchni kr̆idy Čeck. Casopis Národního Muzea, raada přirodovědná 148 (1), 42-49. 